\title{
The Rewards of Nicotine: Regulation by Tissue Plasminogen Activator-Plasmin System through Protease Activated Receptor-1
}

\author{
Taku Nagai, ${ }^{1,2 \star}$ Mina Ito,${ }^{1 \star}$ Noritaka Nakamichi, ${ }^{1}$ Hiroyuki Mizoguchi, ${ }^{1}$ Hiroyuki Kamei, ${ }^{1}$ Ayumi Fukakusa, ${ }^{1}$ \\ Toshitaka Nabeshima, ${ }^{2}$ Kazuhiro Takuma, ${ }^{1}$ and Kiyofumi Yamada ${ }^{1}$ \\ ${ }^{1}$ Laboratory of Neuropsychopharmacology, Division of Life Sciences, Graduate School of Natural Science and Technology, Kanazawa University, Kanazawa \\ 920-1192, Japan, ${ }^{2}$ Department of Neuropsychopharmacology and Hospital Pharmacy, Nagoya University Graduate School of Medicine, Nagoya 466-8560, \\ Japan
}

\begin{abstract}
Nicotine, a primary component of tobacco, is one of the most abused drugs worldwide. Approximately four million people die each year because of diseases associated with tobacco smoking. Mesolimbic dopaminergic neurons mediate the rewarding effects of abused drugs, including nicotine. Here we show that the tissue plasminogen activator (tPA)-plasmin system regulates nicotine-induced reward and dopamine release by activating protease activated receptor-1 (PAR1). In vivo microdialysis revealed that microinjection of either tPA or plasmin into the nucleus accumbens (NAc) significantly potentiated whereas plasminogen activator inhibitor-1 reduced the nicotineinduced dopamine release in the NAc in a dose-dependent manner. Nicotine-induced dopamine release was markedly diminished in tPA-deficient $\left(t P A^{-/-}\right)$mice, and the defect of dopamine release in $t P A^{-/-}$mice was restored by microinjection of either exogenous tPA or plasmin into the NAc. Nicotine increased tPA protein levels and promoted the release of tPA into the extracellular space in the NAc. Immunohistochemistry revealed that PAR1 immunoreactivity was localized to the nerve terminals positive for tyrosine hydroxylase in the NAc. Furthermore, we demonstrated that plasmin activated PAR1 and that nicotine-induced place preference and dopamine release were diminished in PAR1-deficient $\left(P A R 1^{-/-}\right)$mice. Targeting the tPA-plasmin-PAR1 system would provide new therapeutic approaches to the treatment of nicotine dependence.
\end{abstract}

Key words: dependence; behaviors; knock-out mice; protease; dopamine; nucleus accumbens

\section{Introduction}

Nicotine, a primary component of tobacco, is one of the most abused drugs worldwide. It is estimated that nearly two billion people smoke on a regular basis and four million people die each year because of diseases associated with tobacco smoking (Center for Disease Control, 2002). Nicotine rapidly reaches the brain through smoking, and this leads to nicotine dependence. In the $\mathrm{CNS}$, nicotine binds to nicotinic acetylcholine (ACh) receptors (nAChRs). nAChRs are pentameric, ligand-gated ion channels abundant in the CNS (Corringer et al., 2000). Twelve neuronal subunits have been identified, designated $\alpha 2-\alpha 10$ and $\beta 2-\beta 4$, which potentially assemble in multiple combinations with a

Received July 24, 2006; revised 0ct. 23, 2006; accepted 0ct. 25, 2006.

This work was supported in part by Grants-in-Aid for Scientific Research (Grant 17790056) and for the 21st Century COE Program from the Ministry of Education, Culture, Sports, Science, and Technology of Japan; a Grant-inAid for Health Science Research from the Ministry of Health, Labour, and Welfare of Japan; and grants from the Smoking Research Foundation, Japan, Public Health Research Foundation, Mitani Foundation, and Mochida Memorial Foundation for Medical and Pharmaceutical Research. We thank Eizai Company for providing human recombinant tPA.

*T.N. and M.I. contributed equally to this work.

Correspondence should be addressed to Kiyofumi Yamada, Laboratory of Neuropsychopharmacology, Division of Life Sciences, Graduate School of Natural Science and Technology, Kanazawa University, Kakuma-machi, Kanazawa 920-1192, Japan. E-mail: kyamada@p.kanazawa-u.ac.jp.

DOI:10.1523/JNEUROSCI.3139-06.2006

Copyright $\odot 2006$ Society for Neuroscience 0270-6474/06/2612374-10\$15.00/0 broad range of pharmacological and electrophysiological properties (McGehee and Role, 1995). Thus, many nAChR subtypes exist because most subunits can form heteromeric channels, whereas subsets $\alpha 7$ to $\alpha 10$ may form homomeric channels.

Nicotine alters the release of several neurotransmitters, including dopamine, noradrenaline, serotonin, glutamate, GABA, and opioid peptide (Dani and De Biasi, 2001). Mesolimbic dopaminergic neurons, projecting from the ventral tegmental area (VTA) of the midbrain to the nucleus accumbens (NAc), are particularly important and mediate the rewarding effect of nicotine (Picciotto, 2003). The dopaminergic neurons possess highaffinity nAChRs on cell bodies and terminals (Zoli et al., 2002).

Tissue plasminogen activator (tPA), a serine protease that activates plasminogen ( $\mathrm{plg}$ ) to plasmin, plays an important role in fibrinolysis. tPA is also abundantly expressed in the CNS (Sappino et al., 1993). Recent studies have indicated that tPA contributes to the regulation of numerous aspects of synaptic plasticity and remodeling, including neurite outgrowth and neuronal development (Seeds et al., 1999; Jacovina et al., 2001), the late phase of long-term potentiation (Baranes et al., 1998), learning and memory (Calabresi et al., 2000), and excitotoxic neurodegeneration (Tsirka et al., 1995; Siao et al., 2003).

In a previous study, we demonstrated that the tPA-plasmin system participates in the rewarding effect of morphine (Nagai et 
al., 2004, 2005b). Morphine induces tPA expression in the NAc. Targeted deletion of tPA $\left(\mathrm{PPA}^{-/-}\right)$or $\mathrm{plg}\left(\mathrm{plg}^{-/}\right)$significantly diminishes morphine-induced conditioned place preference and hyperlocomotion, being accompanied by a loss of morphineinduced dopamine release in the NAc (Nagai et al., 2004). Pharmacologic inhibition of tPA in the NAc reduces morphineinduced dopamine release (Nagai et al., 2005b). We also demonstrated that $\mathrm{TPA}$ is involved in the rewarding effect of methamphetamine (Nagai et al., 2005a). These findings suggest that the tPA-plasmin system amplifies the rewarding effects of drugs of abuse, by regulating dopamine release in the NAc (Yamada et al., 2005). However, it is unclear whether the tPAplasmin system is activated by other types of addictive drugs, and the mechanism by which this protease system regulates dopamine release in the NAc remains to be determined. Here, we show that the tPA-plasmin system regulates nicotine-induced dopamine release and conditioned place preference through the activation by plasmin of protease activated receptor-1 (PAR1) expressed on dopaminergic neurons. Thus, targeting the tPAplasmin-PAR1 system in the brain may offer new approaches to the treatment of drug dependence.

\section{Materials and Methods}

Animals. Male ICR mice (7 weeks old) were obtained from Japan SLC (Shizuoka, Japan). Wild-type (C57BL/6J), $t P A^{-1-}$ (stock number 002508) (Carmeliet et al., 1994), and $P A R 1^{-1-}$ (stock number 002862) (Connolly et al., 1996) mice were provided by The Jackson Laboratory (Bar Harbor, ME), and the presence or absence of either PAR1, tPA, or the neomycin cassette was verified according to the instructions of the manufacturer. When comparing the wild-type and knock-out forms, only congenic animals were used. All animal care and use was in accordance with the National Institutes of Health Guide for the Care and Use of Laboratory Animals and was approved by the Institutional Animal Care and Use Committee of Kanazawa University.

Preparation of neuronal cultures. Primary neuronal cultures were prepared from hippocampus of 15-d-old embryonic mice (di Porzio et al., 1980). Hippocampi were dissected from embryonic ICR mice and incubated with Versene (Invitrogen, Carlsbad, CA) at room temperature for $12 \mathrm{~min}$. Cells were then mechanically dissociated with a fire-narrowed Pasteur pipette in the culture medium and plated at a density of $1.5 \times 10^{5}$ cells $/ \mathrm{cm}^{2}$ on a 24-well dish in basal DMEM/Nutrient Mixture F-12 (DMEM/F-12) supplemented with 10\% fetal calf serum (FCS) (Dainippon Pharmaceutical, Osaka, Japan), 33 mm glucose, 2 mm glutamine, 100 $\mathrm{U} / \mathrm{ml}$ penicillin, $100 \mu \mathrm{g} / \mathrm{ml}$ streptomycin, $5 \mathrm{~mm}$ HEPES, and $0.11 \%$ sodium bicarbonate. Before use, dishes were sequentially coated with 10 $\mu \mathrm{g} / \mathrm{ml}$ poly-L-lysine. After $18 \mathrm{~h}$ in culture, the culture medium was replaced with basal DMEM/F-12 containing 5\% FCS, $33 \mathrm{~mm}$ glucose, $2 \mathrm{~mm}$ glutamine, $100 \mathrm{U} / \mathrm{ml}$ penicillin, $100 \mu \mathrm{g} / \mathrm{ml}$ streptomycin, $5 \mathrm{~mm}$ HEPES, $0.11 \%$ sodium bicarbonate, $25 \mu \mathrm{g} / \mathrm{ml}$ transferrin, $250 \mathrm{ng} / \mathrm{ml}$ insulin, 0.5 pм $\beta$-estradiol, $1.5 \mathrm{~nm}$ triiodothyronine, $10 \mathrm{~nm}$ progesterone, $4 \mathrm{ng} / \mathrm{ml}$ sodium seleniate, and $50 \mu \mathrm{M}$ putrescine. Cells were treated with $5 \mu \mathrm{M}$ cytosine arabinoside for $24 \mathrm{~h}$ during 2-3 d in vitro (DIV). Cultures were kept in serum-free medium, basal DMEM supplemented with $25.5 \mathrm{~mm}$ glucose, $0.5 \mathrm{~mm}$ glutamine, $100 \mathrm{U} / \mathrm{ml}$ penicillin, $100 \mu \mathrm{g} / \mathrm{ml}$ streptomycin, $0.11 \%$ sodium bicarbonate, $50 \mu \mathrm{g} / \mathrm{ml}$ transferrin, $500 \mathrm{ng} / \mathrm{ml}$ insulin, $1 \mathrm{pM}$ $\beta$-estradiol, $3 \mathrm{~nm}$ triiodothyronine, $20 \mathrm{~nm}$ progesterone, $8 \mathrm{ng} / \mathrm{ml}$ sodium seleniate, and $100 \mu \mathrm{M}$ putrescine after 3 DIV. The culture medium was replaced with a freshly prepared medium of the same composition every $3 \mathrm{~d}$. Cultures were always maintained at $37^{\circ} \mathrm{C}$ in a $5 \% \mathrm{CO}_{2} / 95 \%$ airhumidified incubator.

In vivo microdialysis. Animals were anesthetized with sodium pentobarbital (50 mg/kg, i.p.), and a guide cannula (MI-AG-6; Eicom, Kyoto, Japan) was implanted in the NAc $(+1.5 \mathrm{~mm}$ anteroposterior, $+0.8 \mathrm{~mm}$ mediolateral from bregma, $-4.0 \mathrm{~mm}$ dorsoventral from the skull) according to the mouse brain atlas (Franklin and Paxinos, 1997). On recovery from the surgery, a dialysis probe equipped with a microinjection tube (MIA-6-1; 1 mm membrane length; Eicom) was inserted through the guide cannula and perfused with an artificial CSF (aCSF) (in mm: 147 $\mathrm{NaCl}, 4 \mathrm{KCl}$, and $2.3 \mathrm{CaCl}_{2}$ ) at a flow rate of $1.0 \mu \mathrm{l} / \mathrm{min}$ (Nagai et al., 2004). The microdialysis probes were constructed of three stainless steel tubes, two silica tubes (inlet and outlet) for microdialysis with a $75 \mu \mathrm{m}$ outer diameter, and a microinjection silica tube with a $75 \mu \mathrm{m}$ outer diameter. The microinjection tube was place in parallel with the tubes for microdialysis. The microinjection tube was half the length of the dialysis membrane. These three silica tubes were sealed together with epoxy resin, and each one was secured with stainless steel tubing at the top of the probe. The outflow fractions were collected every $20 \mathrm{~min}$. After the collection of three baseline fractions, plasminogen activator inhibitor-1 (PAI-1) (1-3 ng; Calbiochem, Darmstadt, Germany), human recombinant tPA (30-100 ng; provided by Eisai, Tokyo, Japan), human plasmin (30-100 ng; Chromogenix, Molndal, Sweden), or tyrTRAP7 [( tyr $\left.^{-1}\right)$ thrombin receptor-activating peptide 7; YFLLRNP] (3-10 ng; Bachem, Bubendorf, Switzerland) dissolved in $1 \mu \mathrm{l}$ of aCSF solution was injected during a $10 \mathrm{~min}$ period through the microinjection tube into the NAc. Ten minutes after the microinjection, a dialysis probe was perfused with $1 \mathrm{~mm}$ nicotine containing aCSF for $20 \mathrm{~min}$. Dopamine levels in the dialysates were analyzed using an HPLC system equipped with an electrochemical detector.

For analysis of ACh release, a guide cannula (AG-4; Eicom) was implanted in the hippocampus $(-3.3 \mathrm{~mm}$ anteroposterior, $+3.2 \mathrm{~mm}$ mediolateral from bregma, $-2.5 \mathrm{~mm}$ dorsoventral from the skull) or striatum $(+0.5 \mathrm{~mm}$ anteroposterior, $+2.0 \mathrm{~mm}$ mediolateral from bregma, $-2.8 \mathrm{~mm}$ dorsoventral from the skull). On recovery from the surgery, a dialysis probe (AI-4-2; 2 mm membrane length; Eicom) was inserted through the guide cannula and perfused with an aCSF containing $10 \mu \mathrm{M}$ eserin at a flow rate of $1.0 \mu \mathrm{l} / \mathrm{min}$. Outflow fractions were collected every $15 \mathrm{~min}$. After the collection of three baseline fractions, nicotinecontaining aCSF $(3 \mathrm{~mm})$ was perfused for $30 \mathrm{~min}$. ACh levels in the dialysates were analyzed using an HPLC system equipped with an electrochemical detector (Tran et al., 2001).

In situ zymography. Mice were transcardially perfused with isotonic PBS, pH 7.4, 30 or $60 \mathrm{~min}$ after receiving an injection of nicotine $(0.5$ $\mathrm{mg} / \mathrm{kg}$, s.c.). The brain was then removed, immediately frozen in O.C.T. compound (Sakura Finetechnical, Tokyo, Japan), and stored at $-80^{\circ} \mathrm{C}$. Cryostat sections $(14 \mu \mathrm{m})$ were analyzed for in situ proteinase activity as described previously (Scott et al., 2001), with modifications. Briefly, 100 $\mu \mathrm{l}$ overlays of $1 \%$ agarose in PBS containing $10 \mu \mathrm{g} / \mathrm{ml}$ BODIPY TR-X casein (Invitrogen) and $5 \mathrm{~mm}$ EDTA with or without plasminogen (Chromogenix) were applied to prewarmed tissue and sealed under glass coverslips. The slides were incubated for $4 \mathrm{~h}$ at $37^{\circ} \mathrm{C}$, and then casein fluorescence was observed with a microscope (Axioskop; Zeiss, Oberkochen, Germany). The enzymatic activity of tPA was analyzed with the ATTO Densitograph Software Library CS Analyzer (ATTO Instruments, Tokyo, Japan). All zymograms used for comparisons were processed and photographed at the same time.

Gel zymography. Gel zymography was performed as described previously (Nagai et al., 2004) with minor modifications. Hippocampal neurons cultured for 8-10 DIV were washed with a medium containing 129 $\mathrm{mm} \mathrm{NaCl}, 4 \mathrm{~mm} \mathrm{KCl}, 1 \mathrm{~mm} \mathrm{MgCl} 2,2 \mathrm{~mm} \mathrm{CaCl}_{2}, 4.2 \mathrm{~mm}$ glucose, and 10 mM HEPES, pH 7.4, twice and then stimulated with nicotine for $30 \mathrm{~min}$. The medium was collected and centrifuged at $4^{\circ} \mathrm{C}$ for $10 \mathrm{~min}$ at $15,000 \times$ $g$. The supernatant thus obtained was added at a volume ratio of $1: 1$ to the sample buffer $(0.125$ м Tris-HCl, pH 6.8, 4\% SDS, $0.02 \%$ bromophenol blue, and $20 \%$ glycerol) and loaded onto a $10 \%$ polyacrylamide SDS gel copolymerized with $1 \mathrm{mg} / \mathrm{ml}$ casein and $15 \mu \mathrm{g} / \mathrm{ml}$ plasminogen (Chromogenix). After electrophoresis, the SDS was extracted from the gel by using $2.5 \%$ Triton X-100, and the gel was incubated for $12 \mathrm{~h}$ in $0.1 \mathrm{M}$ Tris- $\mathrm{HCl}, \mathrm{pH} 8.0$, at $37^{\circ} \mathrm{C}$, and stained with Gelcode Blue Stain Reagent (Pierce, Rockford, IL) for $1 \mathrm{~h}$. Destaining with water revealed a transparent zone of supernatant against the dark protein background at $65 \mathrm{kDa}$ corresponding to tPA. The enzymatic activity of tPA was analyzed with the ATTO Densitograph Software Library CS Analyzer (ATTO Instruments).

Measurement of tPA protein. The Assaymax human tPA ELISA kit (ET1001-1; AssayPro, Brooklyn, NY) was used for detecting mouse tPA protein (Mataga et al., 2004). This assay uses a quantitative sandwich 
enzyme immunoassay technique: murine antibody specific for tPA is coated onto a microplate. Mice were transcardially perfused with isotonic PBS $0.5,2,6$, or $24 \mathrm{~h}$ after receiving an injection of nicotine $(0.5$ $\mathrm{mg} / \mathrm{kg}$, s.c.). The brain was then removed, and NAc was homogenized with $50 \mathrm{~mm}$ Tris- $\mathrm{HCl}$ buffer, $\mathrm{pH} 7.4$, containing $1 \%$ Triton X-100. tPA in standards and diluted homogenates was added to microtest plate wells and incubated at $4{ }^{\circ} \mathrm{C}$ overnight. The sample was sandwiched by the immobilized antibody and biotinylated polyclonal antibody specific to tPA for $1 \mathrm{~h}$. Afterward, the tPA complex was recognized by a streptavidinperoxidase conjugate for $30 \mathrm{~min}$. All unbound material was then washed away, and a peroxidase enzyme substrate (chromogen) was added. Color development was stopped with $0.5 \mathrm{M} \mathrm{HCl}$, and intensity was immediately measured at a wavelength of $450 \mathrm{~nm}$.

$\left[{ }^{35} \mathrm{~S}\right] \mathrm{GTP} \gamma \mathrm{S}$ binding assay. $\left[{ }^{35} \mathrm{~S}\right] \mathrm{GTP} \gamma \mathrm{S}$ binding was assessed as described previously (Narita et al., 2005). The tissue was homogenized in $20 \mathrm{vol}(\mathrm{w} / \mathrm{v})$ of an ice-cold $50 \mathrm{~mm}$ Tris- $\mathrm{HCl}$ buffer, $\mathrm{pH}$ 7.4, containing $5 \mathrm{~mm}$ $\mathrm{MgCl}_{2}$ and $1 \mathrm{~mm}$ EGTA. The homogenate was centrifuged at $4^{\circ} \mathrm{C}$ for $10 \mathrm{~min}$ at $48,000 \times g$. The pellet was resuspended in the $\left[{ }^{35} \mathrm{~S}\right] \mathrm{GTP} \gamma \mathrm{S}$ binding assay buffer containing $50 \mathrm{~mm}$ Tris$\mathrm{HCl}, \mathrm{pH}$ 7.4, $5 \mathrm{~mm} \mathrm{MgCl}_{2}, 1 \mathrm{~mm}$ EGTA, and $100 \mathrm{~mm} \mathrm{NaCl}$ and centrifuged at $4^{\circ} \mathrm{C}$ for 10 $\min$ at $48,000 \times g$. The resultant pellet was resuspended in the binding assay buffer. The membrane homogenate (10 $\mu \mathrm{g}$ of protein per assay) was incubated at $25^{\circ} \mathrm{C}$ for $30 \mathrm{~min}$ (for plasmin) or $2 \mathrm{~h}$ (for TRAP7; SFLLRNP) in $1 \mathrm{ml}$ of the binding assay buffer with $30 \mu \mathrm{M}$ GDP and $50 \mathrm{pm}\left[{ }^{35} \mathrm{~S}\right] \mathrm{GTP} \gamma \mathrm{S}$ (specific activity, 1000 $\mathrm{Ci} / \mathrm{mmol}$; GE Healthcare, Little Chalfont, Buckinghamshire, UK) with or without 10$100 \mathrm{~nm}$ plasmin (Chromogenix), 0.1-10 $\mu \mathrm{M}$ TRAP7 (Bachem), or $10 \mu \mathrm{M}$ tyrTRAP7 (Bachem). The reaction was terminated by rapid filtration over GF/B glass filters (Whatman, Middlesex, UK). The filters were washed three times with ice-cold $50 \mathrm{~mm}$ Tris- $\mathrm{HCl}$ buffer, $\mathrm{pH} 7.4$, and transferred to scintillation counting vials containing $1.0 \mathrm{ml}$ of Soluene350 (Packard Instrument, Meriden, CT), and 4 $\mathrm{ml}$ of scintillation mixture (Hionic Fluor; Packard Instrument). Then the radioactivity was determined with a liquid scintillation counter (model LSC-1000; Aloca, Tokyo, Japan). Nonspecific binding was measured in the presence of $10 \mu \mathrm{M}$ unlabeled GTP $\gamma \mathrm{S}$.

Immunohistochemistry. Immunohistochemical analysis for PAR1 and TPA was performed as described previously (Striggow et al., 2001; Nagai et al., 2004). Mice were anesthetized with ether and transcardially perfused with isotonic $0.1 \mathrm{~m}$ phosphate buffer, $\mathrm{pH}$ 7.4, followed by isotonic $4 \%$ paraformaldehyde (PFA). The brain was removed, postfixed in $4 \%$ PFA for $2 \mathrm{~h}$, and then cryoprotected in $30 \%$ sucrose in $0.1 \mathrm{M}$ phosphate buffer. The brain was frozen on dry ice and embedded in TissueTek O.C.T. compound (Sakura Finetechnical). Briefly, sections $(14 \mu \mathrm{m})$ were fixed with $4 \%$ PFA and washed with $0.3 \%$ Triton X-100/PBS. For PAR1 immunostaining, sections were then incubated with an endogenous peroxidase inhibitor $\left(3 \% \mathrm{H}_{2} \mathrm{O}_{2}\right.$ in methanol) for $10 \mathrm{~min}$. Next, they were incubated for $30 \mathrm{~min}$ in blocking serum (5\% normal donkey serum in $0.3 \%$ Triton X-100/PBS) for $48 \mathrm{~h}$ in the presence of goat anti-thrombin receptor (1:50; Santa Cruz
Biotechnology, Santa Cruz, CA) and rabbit anti-tyrosine hydroxylase (TH) (1:200; Chemicon, Temecula, CA). Sections were then incubated in blocking serum containing biotinylated donkey anti-goat $\operatorname{IgG}(1: 200$; Jackson ImmunoResearch, West Grove, PA) and donkey anti-rabbit Alexa Fluor 594 (1:200; Invitrogen) for $60 \mathrm{~min}$. The avidin-biotin complex method followed by the tyramide signal amplification (Invitrogen) procedure was subsequently used to amplify the PAR1 signal, which was visualized with Alexa Fluor 488 conjugated to tyramide.

For tPA immunostaining, slices were incubated for $30 \mathrm{~min}$ in blocking serum (5\% normal goat serum in $0.3 \%$ Triton X-100/PBS) for $24 \mathrm{~h}$ in the presence of rabbit anti-tPA (1:500; Molecular Innovations, Southfield, MI) and monoclonal mouse anti-neuronal-specific nuclear protein
A
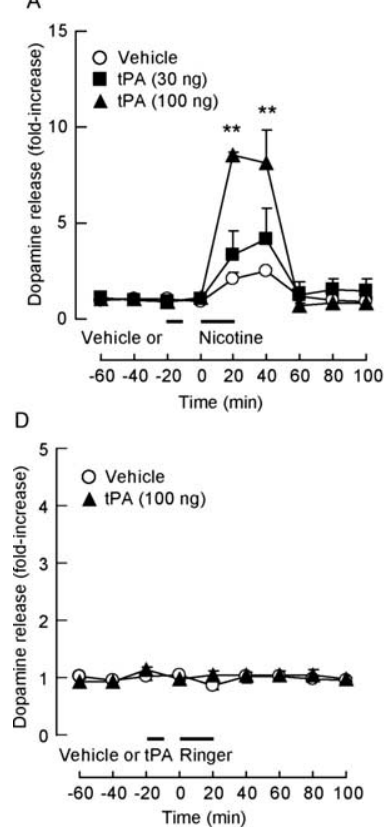
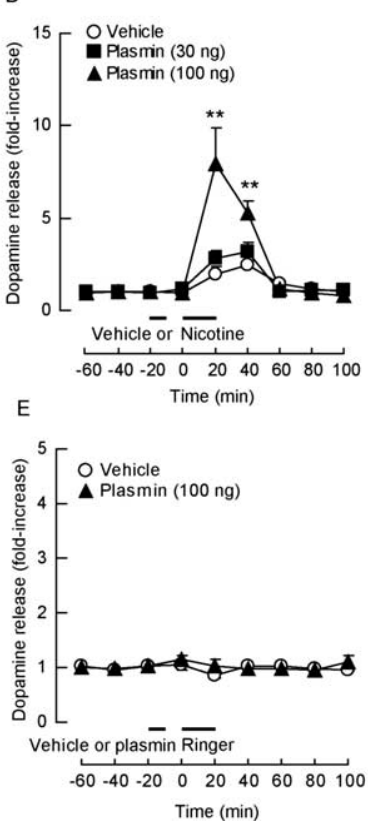
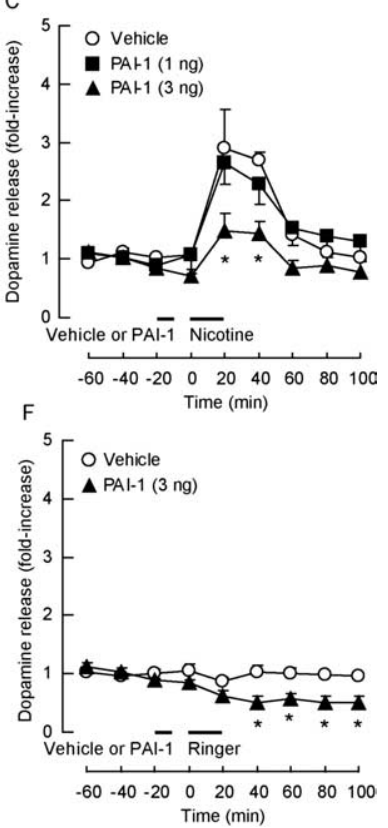

Figure 1. $\quad$ tPA-plasmin system regulates nicotine-induced dopamine release in the NAc. $\boldsymbol{A}-\boldsymbol{C}$, Effect of microinjection of $\mathrm{PAA}$ $(\boldsymbol{A})$, plasmin $(\boldsymbol{B})$, or PAI-1 (C) into the NAc on nicotine-induced dopamine release in the NAc of ICR mice. Microinjection of tPA or plasmin significantly increased nicotine-induced dopamine release $\left(F_{(2,10)}=5.599, p<0.05\right.$ for tPA; $F_{(2,9)}=4.698, p<0.05$ for plasmin). In contrast, microinjection of PAl- 1 into the NAc inhibited the nicotine-induced dopamine release $\left(F_{(2,10)}=7.186, p<\right.$ 0.05). $\boldsymbol{D}-\boldsymbol{F}$, Effect of microinjection of tPA $(\boldsymbol{D})$, plasmin $(\boldsymbol{E})$, or PAl-1 $(\boldsymbol{F})$ into the NAc on dopamine release in the NAc of ICR mice. Microinjection of tPA-plasmin by itself had no effect on the basal level in the NAc. Microinjection of PAl-1 itself slightly but significantly decreased basal extracellular dopamine levels $\left(F_{(1,4)}=13.243 ; p<0.05\right)$. Values represent the mean $\pm \operatorname{SEM}(n=$ $3-6) .{ }^{*} p<0.05$ and ${ }^{* *} p<0.01$ compared with corresponding vehicle-treated group.
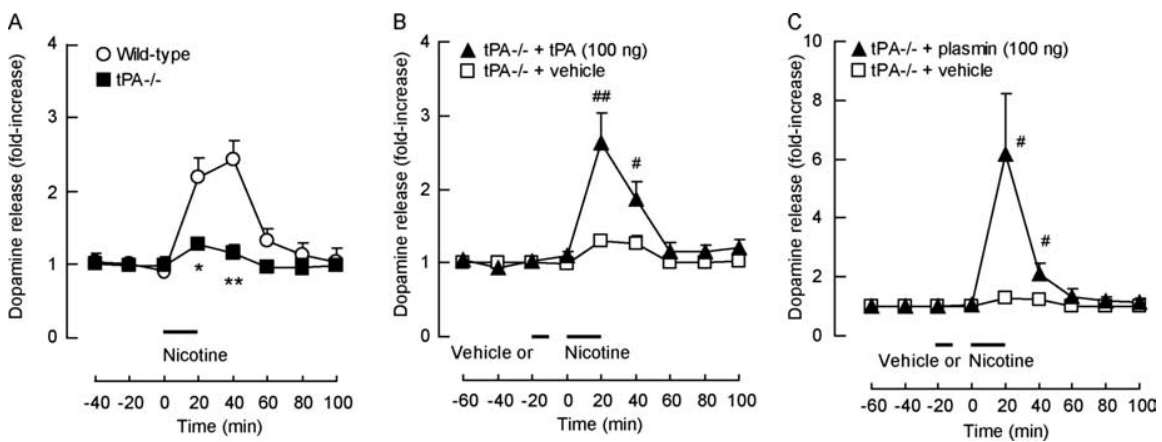

Figure 2. Nicotine-induced dopamine release in the NAc of $t P A^{-/-}$and wild-type mice. $A$, Basal levels of dopamine in the NAC did not differ between wild-type and $t P A^{-/-}$mice (wild-type, $0.90 \pm 0.11 \mathrm{~nm} ; P A^{-/-}, 0.84 \pm 0.08 \mathrm{~nm}$ ). Nicotine-induced dopamine release was markedly diminished in $t P A^{-/-}$mice $\left(F_{(1,6)}=11.273 ; p<0.05\right)$. $\boldsymbol{B}$, C, Effect of microinjection of $\operatorname{tPA}(\boldsymbol{B})$ or plasmin $(C)$ into the NAc on nicotine-induced dopamine release in the NAc of $t P A^{-1}$ mice. Microinjection of tPA or plasmin into the NAc restored the nicotine-induced dopamine release in $t P A^{-/-}$mice $\left(F_{(1,8)}=8.882, p<0.05\right.$ for tPA; $F_{(1,9)}=8.519, p<$ 0.05 for plasmin). Values represent the mean \pm SEM $(n=4-6)$. ${ }^{*} p<0.05$ and ${ }^{* *} p<0.01$ compared with corresponding vehicle-treated wild-type mice. ${ }^{\#} p<0.05$ and ${ }^{\# \#} p<0.01$ compared with corresponding vehicle-treated $t P A^{-/-}$mice. 

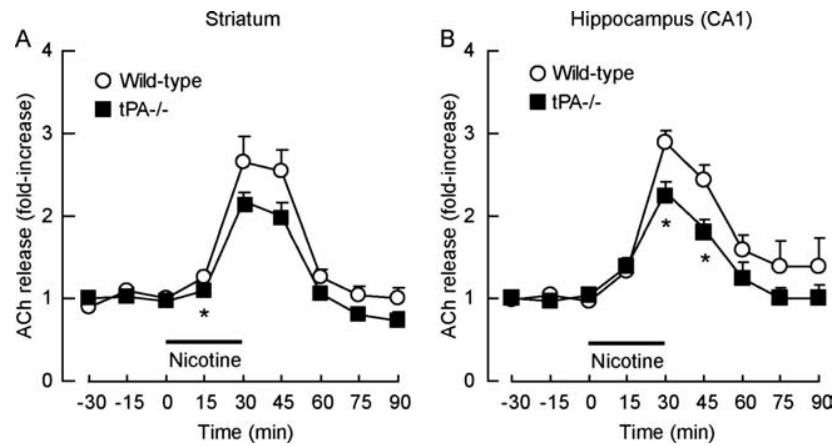

Figure 3. $\boldsymbol{A}, \boldsymbol{B}$, Nicotine-induced $\mathrm{ACh}$ release in the striatum $(\boldsymbol{A})$ and hippocampal $C A 1$ subfield $(\boldsymbol{B})$ of $t P A^{-1-}$ mice and wild-type mice. Basal levels of $A C h$ in the striatum are as follows: wild-type, $437.6 \pm 77.4 \mathrm{~nm}, t P A^{-/-}, 526.2 \pm 61.3 \mathrm{~nm}$. Basal levels in the hippocampal CA1 are as follows: wild-type, $52.8 \pm 4.5 \mathrm{~nm} ; \mathrm{tPA^{-/ }}, 71.6 \pm 11.4 \mathrm{~nm}$. Nicotine $(3 \mathrm{~mm})-$ induced ACh release was slightly but significantly decreased in the striatum $\left(F_{(1,10)}=5.604\right.$; $p<0.05)$ and hippocampal CA1 subfield $\left(F_{(1,10)}=5.057 ; p<0.05\right)$ of $t P A^{-/-}$mice. Values represent the mean $\pm \operatorname{SEM}(n=6) .{ }^{*} p<0.05$ compared with corresponding wild-type mice.
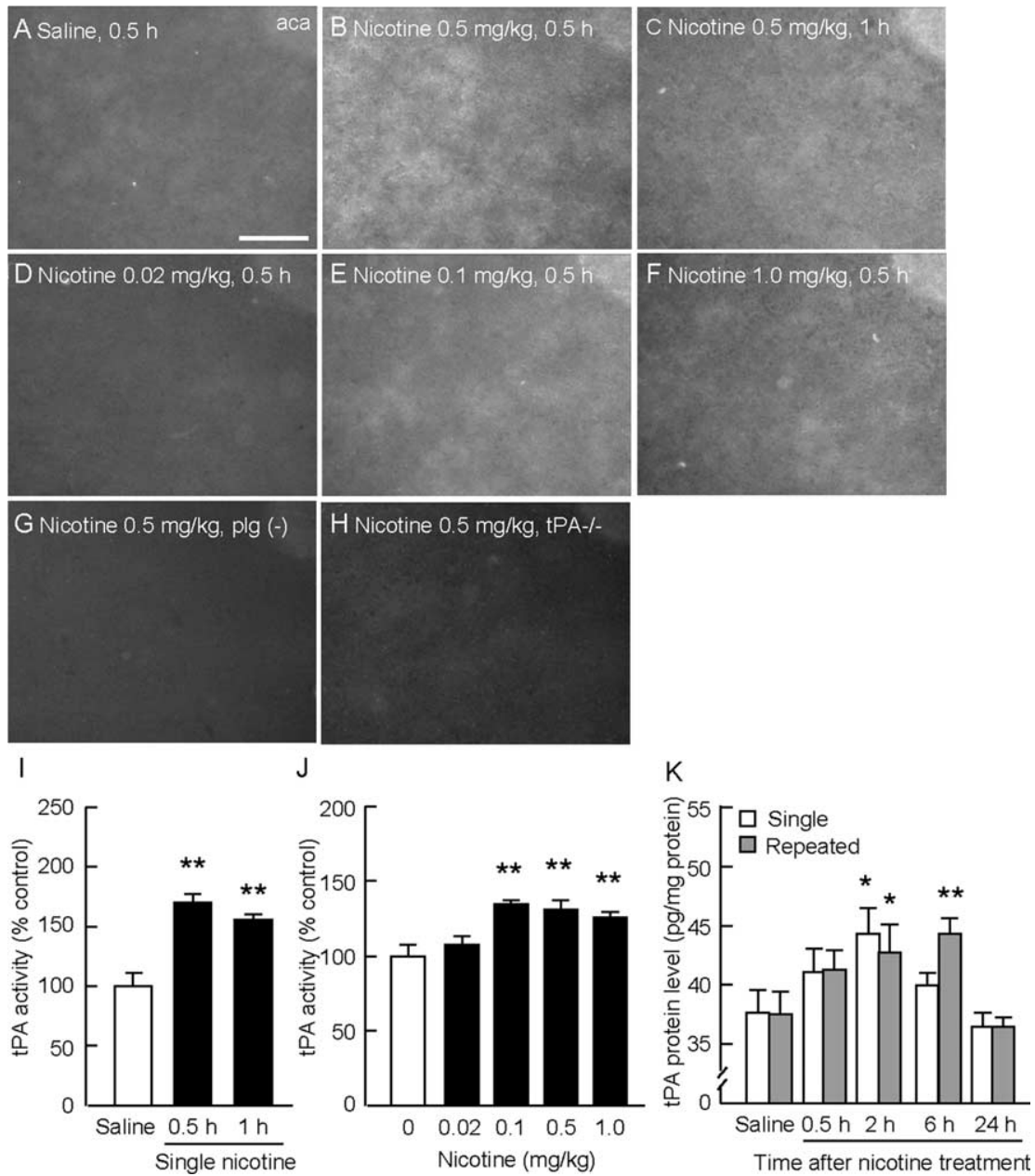

Figure 4. Nicotine increases extracellular tPA activity in the NAc in vivo. $\boldsymbol{A}-\boldsymbol{H}$, Time course and dose-response effects of single nicotine treatment on extracellular tPA activity. Mice were perfused with isotonic PBS $0.5 \mathrm{~h}(\boldsymbol{B}, \boldsymbol{D}-\boldsymbol{H})$ or $1 \mathrm{~h}(\boldsymbol{C})$ after subcutaneous injection of nicotine or saline (A). $\boldsymbol{I}, \boldsymbol{J}$, Quantification of the changes shown in $\boldsymbol{A}-\boldsymbol{H}$. $\boldsymbol{A}-\boldsymbol{C}, \boldsymbol{I}$, Extracellular tPA activity was significantly increased $0.5 \mathrm{~h}(\boldsymbol{B})$ and $1 \mathrm{~h}(\boldsymbol{C})$ after the single nicotine treatment compared with the saline-treated control $(\boldsymbol{A})\left(F_{(2,10)}=\right.$ 33.139; $p<0.01 ; n=4-5) . \boldsymbol{B}, \boldsymbol{D}-\boldsymbol{F}, \boldsymbol{J}$, Nicotine-increased extracellular tPA activity in the NAc in a dose-dependent manner $\left(0.02-1.0 \mathrm{mg} / \mathrm{kg}\right.$, s.c.) $\left(F_{(4,21)}=7.984 ; p<0.01 ; n=3-6\right) . \boldsymbol{G}, \boldsymbol{H}$, No caseinolytic activity was detected in the nicotine-treated mice in the absence of $\operatorname{plg}(\boldsymbol{G})$ or in $t P A^{-1-}$ mice $(\boldsymbol{H})$. Scale bar, $200 \mu \mathrm{m}$. $\boldsymbol{K}$, Time course of changes in tPA protein levels after single or repeated nicotine $(0.5 \mathrm{mg} / \mathrm{kg}$, s.c.) treatment. The protein levels of tPA in the NAc significantly increased after nicotine treatment $\left(F_{(3,90)}=3.155 ; p<0.01 ; n=4\right)$. Values represent the mean \pm SEM. ${ }^{*} p<0.05$ and ${ }^{* *} p<0.01$ compared with corresponding saline-treated control group. aca, Anterior commissure anterior part.
(NeuN) (1:500; Chemicon) antibodies. Sections were then incubated in goat anti-rabbit Alexa Fluor 594 (1:200; Invitrogen) and goat anti-mouse th a confocal microscope (model LSM510; Zeiss).

Conditioned place preference test. The conditioned place preference test apparatus consisted of two compartments: a transparent Plexiglas box and a black Plexiglas box $(16 \times 16 \times 7 \mathrm{~cm})$. To enable a mouse to uneven Plexiglas and that of the black box with smooth black Plexiglas. All sessions were conducted under conditions of dim illumination (40 lux place conditioning schedule consisted of three phases: preconditioning, conditioning, and postconditioning. In the preconditioning phase, the mouse was allowed to move freely between the boxes was measured using a MED-PC IV (Neuroscience Idea, Osaka, Japan). itioning was counterbalanced between compartments to use ensure the procedure was unbiased. No initial place preference or aversion to the two compartments was observed in the experiment. During the conditioning phase, mice were treated for $6 \mathrm{~d}$ with alternate injections of nicotine $(0.02$ or $0.5 \mathrm{mg} / \mathrm{kg}$, s.c.) or saline. On days 4,6 , and 8 , they were treated with nicotine and confined in the transparent or black box for $60 \mathrm{~min}$. On days 5, 7, and 9, they were given saline and confined in the other box for $60 \mathrm{~min}$. Control animals received saline every day. On day 10 , the postconditioning phase was performed similar to the preconditioning phase, i.e., free access to both compartments for $15 \mathrm{~min}$, and the time spent in each of the boxes was measured. Conditioned place preference was calculated for each mouse as the difference in time spent on the nicotine-conditioned side and salineconditioned side in the postconditioning phase on day 10.

Statistical analysis. All data were expressed as the mean \pm SEM. In the analysis of the time course for the microdialysis, an ANOVA with repeated measures was used and followed by the Bonferroni's test when $F$ ratios were significant $(p<0.05)$. Statistical differences between two sets of groups were determined with the Mann-Whitney $U$ test. In the analysis of tPA activity and protein levels, $\left[{ }^{35} \mathrm{~S}\right] \mathrm{GTP} \gamma \mathrm{S}$ binding, and conditioned place preference, an ANOVA was used, followed by the Bonferroni's test when $F$ ratios were significant $(p<$ 0.05).

\section{Results}

tPA-plasmin system increases nicotineinduced dopamine release in the NAc

To investigate whether the tPA-plasmin system is involved in the activation of dopaminergic neurons by nicotine, we studied the effect of microinjections of exogenous tPA, plasmin, or PAI-1 into the NAc on nicotine (1 $\mathrm{mm}$ )-induced dopamine release by in vivo microdialysis in which a probe was inserted into the NAc to allow the collection of samples in conscious, freely moving mice (Fig. 1). The dopamine levels in the NAc of vehiclemicroinjected mice were markedly increased by nicotine, which was perfused through a dialysis probe for $20 \mathrm{~min}$ (Fig. $1 A)$. This nicotine-induced dopamine re- 
lease was dose-dependently potentiated by microinjection of tPA or plasmin into the NAc $(p<0.05)$ (Fig. $1 A, B)$. In contrast, microinjection of PAI-1 into the NAc dose dependently inhibited the nicotine-induced increase in extracellular dopamine levels $(p<0.05)$ (Fig. 1C). Microinjection of tPA (100 ng/site) and plasmin $(100 \mathrm{ng} / \mathrm{site})$ by themselves had no effect on the basal levels in the NAc (Fig. $1 D, E$ ), whereas PAI-1 (3 ng/site) slightly but significantly decreased basal extracellular dopamine levels $(p<0.05)$ (Fig. $1 F)$, suggesting that the endogenous tPAplasmin system regulates dopamine release in the NAc. Together, these results indicate that the $\mathrm{PA}$-plasmin system regulates nicotine-induced dopamine release in the NAc of ICR mice.

To confirm the involvement of endogenous tPA in nicotine-induced dopamine release, we measured the amount of dopamine released in $t \mathrm{PA}^{-/-}$mice. Dopamine levels in the NAc were markedly increased by nicotine stimulation in wild-type mice (Fig. $2 A$ ) but were diminished in $t P A^{-/-}$ mice $(p<0.05)$ (Fig. $2 A)$. Microinjection of either recombinant $\mathrm{tPA}$ ( $100 \mathrm{ng} / \mathrm{site})$ or plasmin (100 ng/site) into the NAc dramatically restored the level of dopamine in $t P A^{-/-}$mice $(p<0.05)$ (Fig. $2 B, C$ ). These results suggest that the defect in nicotine-induced dopamine release in $t P A^{-/-}$mice is attributable to a deficiency of tPA in the NAc, not to a developmental malfunction. Furthermore, tPA modulates nicotine-induced dopamine release probably by converting plg to plasmin in the NAc.

\section{tPA-plasmin system increases nicotine- induced $\mathrm{ACh}$ release in the NAc}

It is well known that nicotine stimulates the release of not only dopamine but also ACh (Tran et al., 2001). Because it is possible that the release of ACh may also be modulated by the tPA-plasmin system, we examined the nicotineinduced $\mathrm{ACh}$ release in the striatum and hippocampus of $t P A^{-/-}$ mice. Basal levels of ACh in the striatum and hippocampus did not differ between wild-type and $t P A^{-/-}$mice. Nicotine-induced ACh release was slightly but significantly decreased in the striatum $(p<0.05)$ (Fig. $3 A)$ and the hippocampal CA1 subfield $\left(p<0.05\right.$ ) (Fig. 3B) of $t P A^{-/-}$mice.

\section{Nicotine increases tPA activity and protein levels in the NAc}

tPA is stored in synaptic vesicles in the nervous system and released into the extracellular space by a depolarization stimulus (Gualandris et al., 1996; Lochner et al., 2006). Thus, if nicotineinduced dopamine release is modulated under the control of the tPA-plasmin system, nicotine should increase extracellular tPA activity in the NAc. We examined tPA activity in the NAc after nicotine administration by in situ zymography because this method indicates the localization of extracellular protease activity (Sappino et al., 1993). Single nicotine treatment $(0.5 \mathrm{mg} / \mathrm{kg})$ significantly increased tPA activity in the NAc $0.5 \mathrm{~h}(170 \%)$ and $1 \mathrm{~h}(155 \%)$ after the treatment $(p<0.01)$ (Fig. $4 A-C, I)$. The effect of nicotine was dose dependent $(p<0.01)$ (Fig. $4 D-F, J)$ and completely inhibited by pretreatment with the nAChR antagonist mecamylamine $(p<0.01)$ (Fig. $5 A-C, F)$. Furthermore, nicotine-induced increase in extracellular tPA activity in the NAc was inhibited by pretreatment with either dopamine $\mathrm{D}_{1}$ antagonist SCH23390 $[R(+)$-7-chloro-8-hydroxy-3-methyl-1-phenyl2,3,4,5-tetrahydro-1 $H$-3-benzazepine hydrochloride] $(p<0.01)$ (Fig. $5 D, G)$ or dopamine $\mathrm{D}_{2}$ receptor antagonist raclopride $(p<$ 0.01 ) (Fig. $5 E, G$ ). These results suggest that nicotine stimulates release of $\mathrm{tPA}$ through both $\mathrm{nACh}$ and dopamine receptors. Repeated nicotine treatment $(0.5 \mathrm{mg} / \mathrm{kg}$ for $5 \mathrm{~d})$ increased $\mathrm{tPA}$ activity as did the single treatment (data not shown). We confirmed that no caseinolytic activity was detected when plg was omitted from the overlay matrix (Fig. $4 G$ ). Moreover, nicotine failed to increase tPA activity in $t P A^{-/-}$mice (Fig. $4 H$ ).

We also examined the effect of nicotine on the protein expression of tPA in the NAc by ELISA. The protein levels of tPA were significantly increased $2 \mathrm{~h}(118 \%)$ after single nicotine treatment 

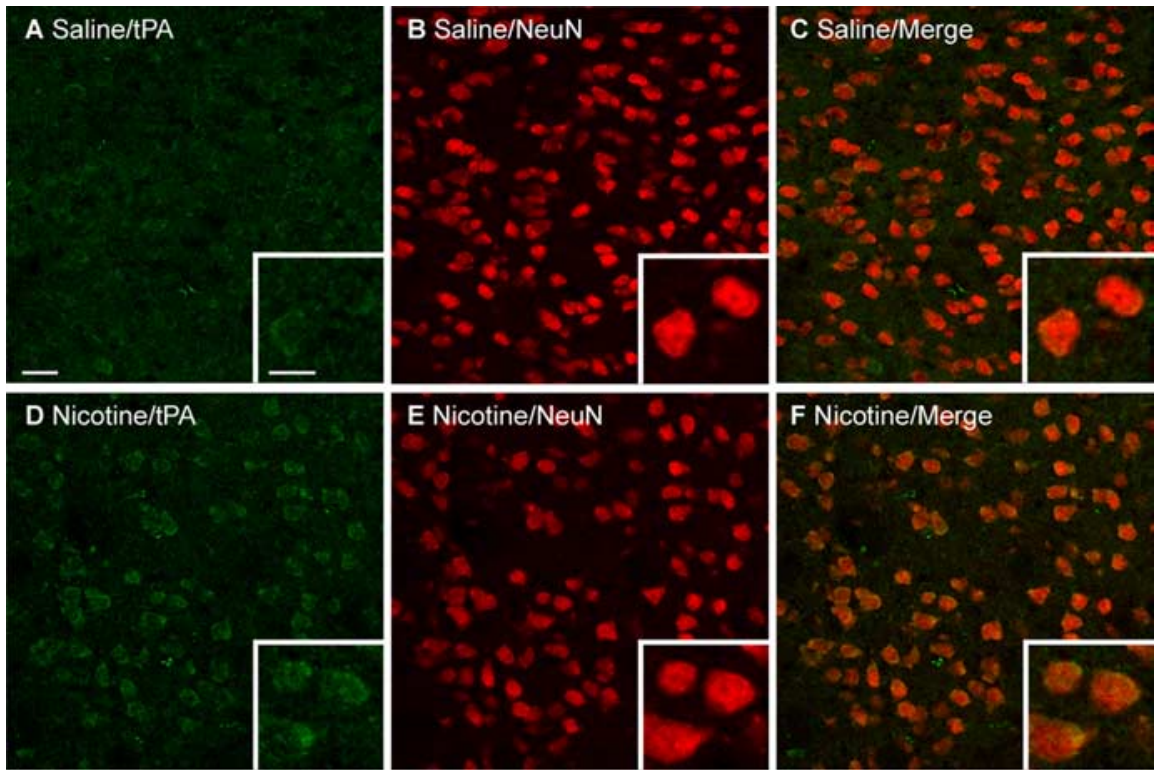

Figure 6. $\quad$ tPA expression in the NAc after nicotine treatment. Immunohistochemical analysis was conducted $2 \mathrm{~h}$ after the nicotine $(0.5 \mathrm{mg} / \mathrm{kg}$, S.c.) treatment. $\boldsymbol{A}$, tPA immunoreactivity in saline-treated mice. $\boldsymbol{B}$, NeuN immunoreactivity in saline-treated mice. $\boldsymbol{C}$, Merged image of $\boldsymbol{A}$ and $\boldsymbol{B}$. $\boldsymbol{D}, \mathrm{tPA}$ immunoreactivity in nicotine-treated mice. $\boldsymbol{E}$, NeuN immunoreactivity in nicotinetreated mice. $\boldsymbol{F}$, Merged image of $\boldsymbol{D}$ and $\boldsymbol{E}$. Scale bars: $\boldsymbol{A}, 20 \mu \mathrm{m}$; inset in $\boldsymbol{A}, 10 \mu \mathrm{m}$.

A

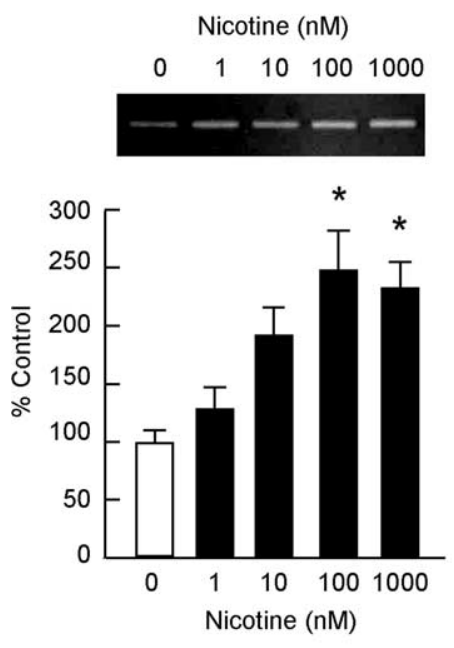

B
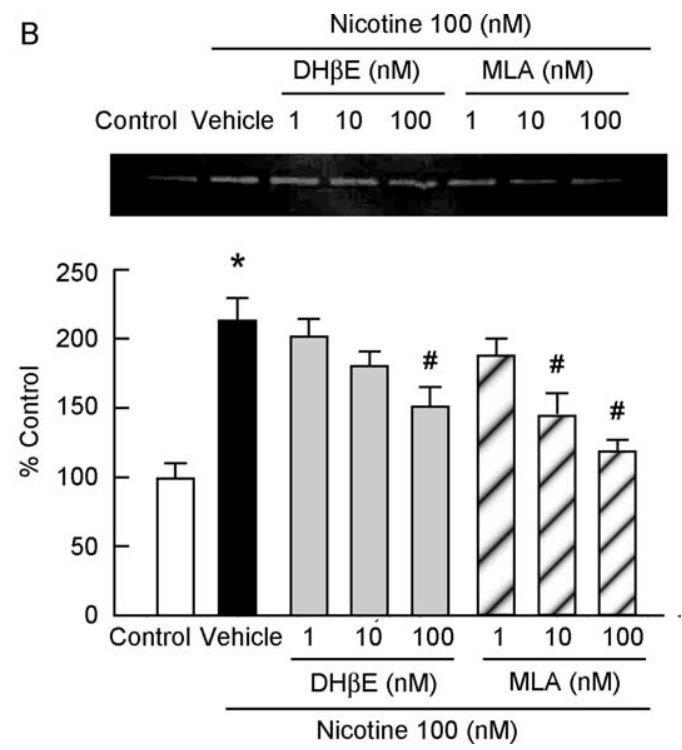

Figure 7. Stimulation of tPA release by nicotine from hippocampal neurons in culture. $\boldsymbol{A}$, Hippocampal neurons in culture (9-10 DIV) were treated with increasing concentrations of nicotine (1-1000 nM) for $30 \mathrm{~min}$, and the level of tPA activity in the conditioned medium was examined by gel zymography. Nicotine treatment resulted in a significant increase in $\mathrm{PA}$ activity $\left(F_{(4,}\right.$ 20) $=8.382 ; p<0.01)$. $B$, Activation of $\alpha 4 \beta 2$ and $\alpha 7 \mathrm{nAChRs}$ is required for nicotine-induced tPA release. The $\alpha 4 \beta 2 \mathrm{nAChR}$ antagonist dihydro- $\beta$-erythroidine ( $\mathrm{DH} \beta \mathrm{E})$ and $\alpha 7 \mathrm{nAChR}$ antagonist methyllycaconitine (MLA) inhibited the nicotine-induced tPA release $\left(F_{(7,32)}=11.119 ; p<0.01\right)$. Values represent the mean $\pm \operatorname{SEM}(n=5) .{ }^{*} p<0.05$ compared with control group. ${ }^{\#} p<0.05$ compared with nicotine (100 nm)-treated group.

and then returned to the control value $24 \mathrm{~h}$ after the treatment $(p<0.01)$ (Fig. $4 K)$. Repeated nicotine treatment also increased tPA protein levels $2 \mathrm{~h}(114 \%)$ and $6 \mathrm{~h}(118 \%)$ after the final injection $(p<0.01)$ (Fig. $4 K)$. Immunohistochemistry revealed that IPA immunoreactivity was localized to cells positive for $\mathrm{NeuN}$, a marker of neuronal cells, in the NAc, and the signals in nicotine-treated animals were apparently more intense than those in saline-treated animals (Fig. 6). It is possible that the speckled tPA immunoreactivity, which does not merge with
NeuN, may indicate tPA-containing dense-core granules in dendrites because tPA resides in dense-core granules of dendrites (Lochner et al., 2006).

To confirm the nicotine-induced tPA release from neurons, we stimulated cultured hippocampal neurons with nicotine and measured the tPA activity released into the medium by gel zymography. Addition of nicotine to the culture medium resulted in a concentration-dependent increase in tPA activity $(p<0.01)$ (Fig. $7 A)$. Furthermore, the nicotine-induced tPA release was blocked completely by pretreatment with the selective $\alpha 7$ subunitcontaining $\mathrm{nAChR}(\alpha 7 \mathrm{nAChR})$ antagonist methyllycaconitine and partially by the $\alpha 4 \beta 2$ subunit-containing $\mathrm{nAChR}$ $(\alpha 4 \beta 2$ nAChR) antagonist dihydro- $\beta$ erythroidine $(p<0.05)$ (Fig. $7 B)$. Together, these results suggest that nicotine directly promotes the release of tPA from neurons via the activation of both $\alpha 7$ and $\alpha 4 \beta 2$ nAChRs.

\section{PAR1 mediates the regulation of} nicotine-induced dopamine release by plasmin

Next, we sought to determine the mechanisms by which the tPA-plasmin system regulates nicotine-induced dopamine release in the NAc. Plasmin is known to degrade several extracellular matrix proteins such as laminin (Nakagami et al., 2000) and converts pro-brain-derived neurotrophic factor to its mature form (Lee et al., 2001). Alternatively, plasmin was demonstrated recently to activate PAR1 (Kuliopulos et al., 1999). Interestingly, a previous study demonstrated high levels of PAR1 mRNA in dopaminergic neurons in the substantia nigra/VTA (Weinstein et al., 1995). This may explain the relatively selective effect of the tPA-plasmin system on dopamine release in the NAc compared with ACh release. Accordingly, we focused on the role of PAR1 in the regulation of dopamine release by the tPA-plasmin system.

PAR1 belongs to the cell-surface G-protein-coupled receptor family and has seven transmembrane domains and an extracellular N terminus (Vu et al., 1991). Proteolytic activation of the receptor by serine proteases, including thrombin and plasmin, at the $\mathrm{N}$ terminus results in unmasking of the tethered ligand sequence, which then binds to a specific binding site for the tethered ligand on extracellular loop 2 and causes receptor activation (Grand et al., 1996; Dery et al., 1998). To demonstrate PAR1 protein expression on dopaminergic neurons, immunohistochemistry with specific PAR1 antibodies was performed. PAR1 immunoreactivity in the NAc appears to be partially colocalized with $\mathrm{TH}$, a marker for dopaminergic neurons (Fig. 8A-C). Moreover, colo- 
calization with PAR1 and TH was observed in the VTA (Fig. 8D-F).

We also demonstrated by assaying $\left[{ }^{35} \mathrm{~S}\right] \mathrm{GTP} \gamma \mathrm{S}$ binding that plasmin activates PAR1 in the brain. A PAR1 agonist peptide, TRAP7, increased $\left[{ }^{35} \mathrm{~S}\right] \mathrm{GTP} \gamma \mathrm{S}$ binding in the striatal membranes containing the NAc by up to $43 \%$ above the basal level in a concentration-dependent manner (Fig. 9A), and the effect was completely inhibited by a PAR1 antagonist peptide, tyrTRAP7 ( $p<0.01)$ (Fig. 9B). Plasmin also increased $\left[{ }^{35} \mathrm{~S}\right] \mathrm{GTP} \gamma \mathrm{S}$ binding (Fig. 9C), which was antagonized by tyrTRAP7 $(p<0.05)$ (Fig. 9D). These results suggest the functional expression of PAR1 in the presynaptic dopaminergic neurons, which is activated by the tPAplasmin system.

To demonstrate the involvement of PAR1 in the regulation by the tPA-plasmin system of nicotine-induced dopamine release, we examined the effect of a PAR1 antagonist peptide on nicotineinduced dopamine release in the NAc. Microinjection of tyrTRAP7 (10 ng/site) into the NAc significantly reduced nicotine-induced dopamine release $(p<0.05)$ (Fig. $10 \mathrm{~A}$ ), although the antagonist had no effect on basal dopamine levels (Fig. $10 \mathrm{~B}$ ). We also examined the effect of the PAR1 antagonist on the ameliorating effect of plasmin against the defect of nicotine-induced dopamine release in $t P A^{-/-}$mice. Comicroinjection of tyrTRAP7 with plasmin into the NAc significantly reduced nicotine-induced dopamine release compared with the control $(p<0.01)$ (Fig. 10C). In addition to conducting these pharmacological experiments, we examined the effect of the genetic manipulation of PAR1. Nicotine-induced dopamine release in the NAc was markedly diminished in $P A R 1^{-/-}$mice compared with wild-type mice $(p<0.05)$ (Fig. 10D). These results suggest that PAR1 expressed in the dopaminergic nerve terminals is an essential component for the modulation of nicotine-induced dopamine release by the tPA-plasmin system.

\section{Nicotine-induced conditioned place preference in $\mathrm{tPA}^{-/-}$and $P A R 1^{-/-}$mice}

Finally, to clarify the physiological significance of the regulation of nicotine-induced dopamine release by the tPA-plasminPAR1 signaling, we compared the rewarding effects of nicotine in wild-type, $t P A^{-/-}$, and $P A R 1^{-/-}$mice, in the conditioned place preference test. Nicotine at a conditioning dose of $0.5 \mathrm{mg} / \mathrm{kg}$ induced place preference to the drug-paired side in wild-type mice, whereas saline treatment had no effect on place preference $(p<0.01)$ (Fig. 11A). As expected, the rewarding effects of nicotine were markedly diminished in $t P A^{-/-}$mice $(p<0.01)$ (Fig. $11 A)$. Moreover, nicotine failed to induce place preference in $P A R 1^{-1-}$ mice $(p<0.05)$ (Fig. $\left.11 B\right)$. Together, these results suggest that both TPA and PAR1 play a role in the rewarding effects of nicotine.

\section{Discussion}

Nicotine, like other drugs of abuse, activates the mesolimbic dopaminergic system and increases extracellular dopamine levels in the NAc (Pontieri et al., 1996), a feature related to its rewarding properties. The activation of nAChRs located in the NAc and
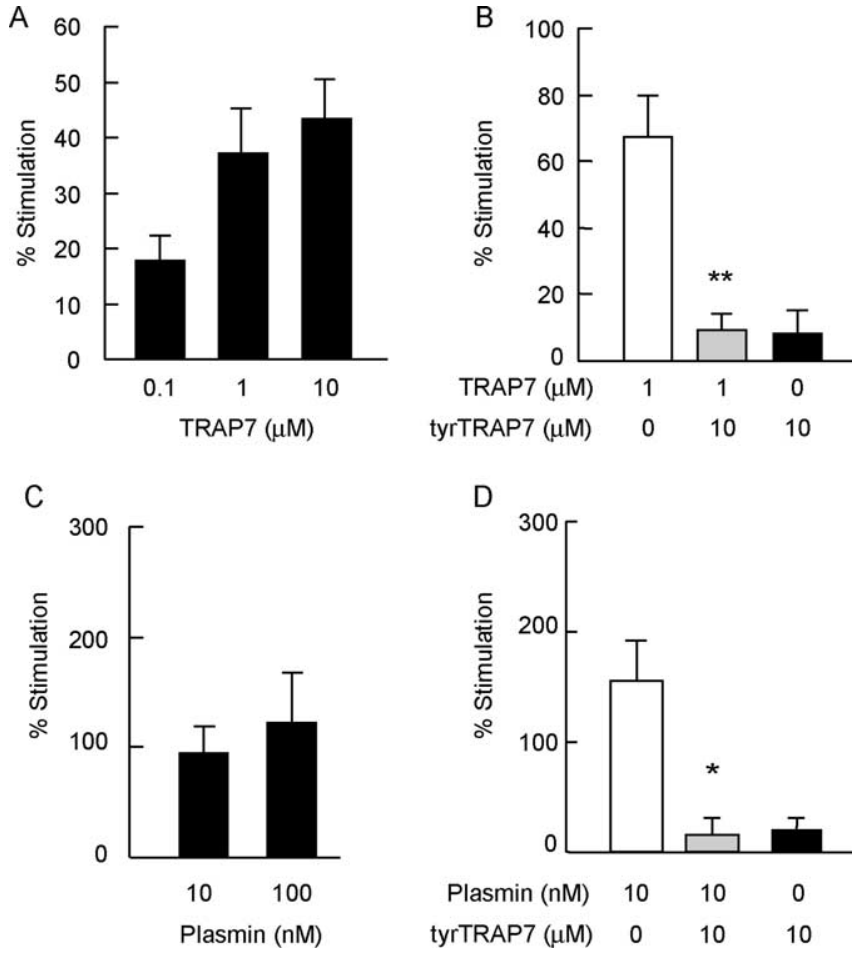

Figure 9. Plasmin activates PAR1 in the striatal membranes. $A$, The PAR1 agonist peptide TRAP7 increased $\left[{ }^{35} \mathrm{~S}\right] \mathrm{GTP} \gamma \mathrm{S}$ binding in striatal membranes containing the NAC in a concentration-dependent manner $\left(F_{(2,15)}=3.935 ; p<0.05\right)$. Basal $\left[{ }^{35} \mathrm{~S}\right] \mathrm{GTP} \gamma \mathrm{S}$ binding is $91.8 \pm 4.7 \mathrm{fmol} / \mathrm{mg}$ protein. $\boldsymbol{B}$, The PAR1 antagonist peptide tyrTRAP7 completely inhibited TRAP7-induced [ $\left.{ }^{35} \mathrm{~S}\right] \mathrm{GTP} \gamma \mathrm{S}$ binding $\left(F_{(2,9)}=15.457 ; p<0.01\right)$. Basal $\left[{ }^{35} \mathrm{~S}\right] \mathrm{GTP} \gamma \mathrm{S}$ binding is $65.8 \pm 3.4 \mathrm{fmol} / \mathrm{mg}$ protein. $C$, Plasmin increased $\left[{ }^{35} \mathrm{~S}\right] \mathrm{GTP} \gamma \mathrm{S}$ binding in striatal membranes in a concentration-dependent manner. Basal $\left[{ }^{35} \mathrm{~S}\right] \mathrm{GTP} \gamma \mathrm{S}$ binding is $16.7 \pm 2.4 \mathrm{fmol} / \mathrm{mg}$ protein. $D$, The effect of plasmin was completely inhibited by tyrTRAP7 $\left(F_{(2,13)}=6.263 ; p<0.05\right)$. Basal $\left[{ }^{35} \mathrm{~S}\right] \mathrm{GTP} \gamma \mathrm{S}$ binding is $15.6 \pm 2.7 \mathrm{fmol} / \mathrm{mg}$ protein. Values represent the mean $\pm \mathrm{SEM}(n=$ $4-8){ }^{*} p<0.05$ and ${ }^{* *} p<0.01$ compared with TRAP7 or plasmin-treated group. 


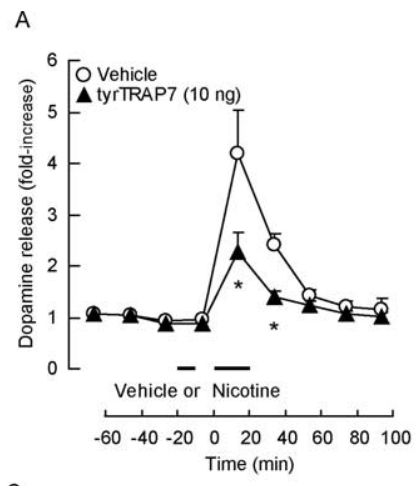

C
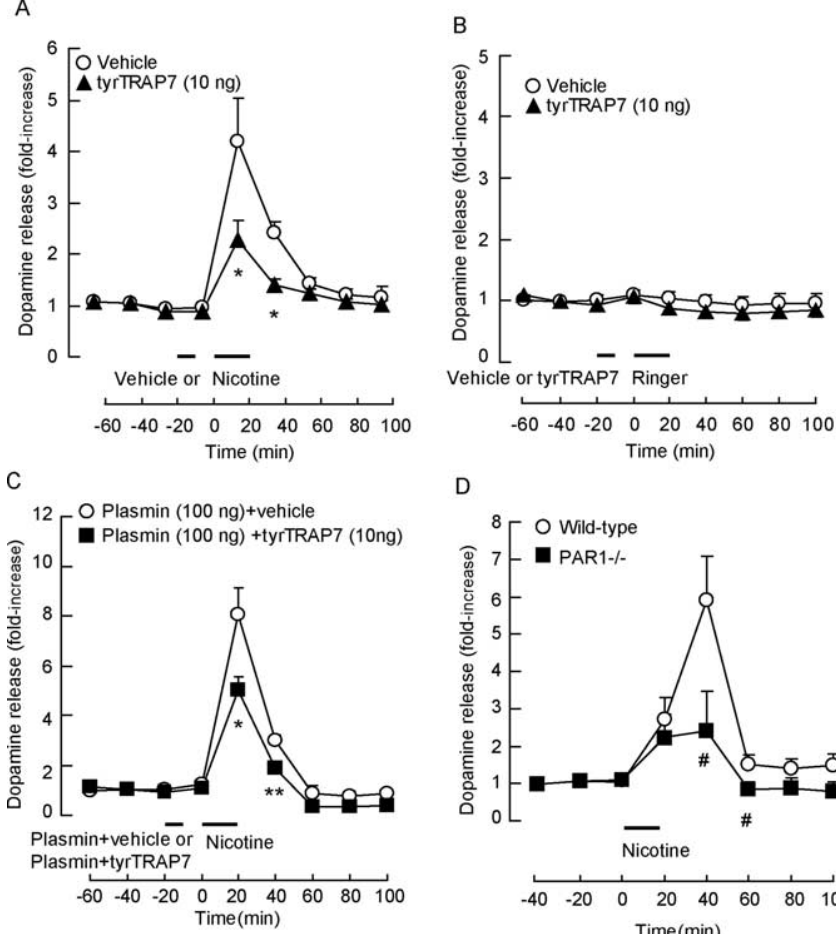

D

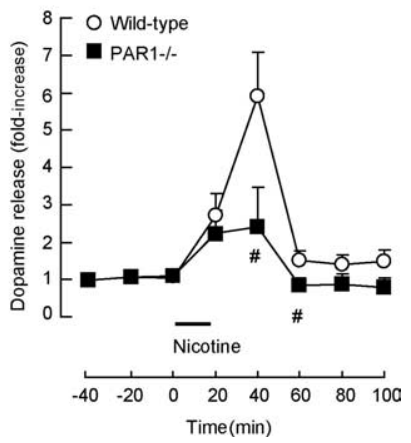

Figure 10. PAR1 mediates the modulation by plasmin of nicotine-induced dopamine release. $\boldsymbol{A}, \boldsymbol{B}$, Effect of tyrTRAP7 on nicotine-induced dopamine release in the NAc. $\boldsymbol{A}$, Microinjection of tyrTRAP7 into the NAc significantly reduced nicotine-induced dopamine release $\left(F_{(1,12)}=6.687 ; p<0.05\right)$. B , Microinjection of tyrTRAP7 by itself had no effect on the basal level in the NAc. $C$, Effect of tyrTRAP7 on the restoration by plasmin of the nicotine-induced dopamine release in $\mathrm{PA}^{-/-}$mice. Microinjection of tyrTRAP7 with plasmin into the NAc significantly inhibited the ameliorating effect of plasmin on nicotine-induced dopamine release in $t P A^{-1-}$ mice $\left(F_{(1,10)}=13.799 ; p<0.01\right)$. D, Nicotine-induced dopamine release in the NAc of $P A R 1^{-1-}$ and wild-type mice. Basal levels of dopamine in the NAc did not differ between wild-type and $P A R 1^{-/-}$mice (wild-type, $0.43 \pm 0.16 \mathrm{~nm} ; P A R 1^{-/-}, 1.22 \pm 0.60 \mathrm{~nm}$ ). Nicotine-induced dopamine release was markedly diminished in $P A R 1^{-/-}$mice $\left(F_{(1,11)}=\right.$ 5.484; $p<0.05)$. Values represent the mean \pm SEM $(n=4-8) .{ }^{*} p<0.05$ and ${ }^{* *} p<0.01$ compared with corresponding vehicle-treated group. ${ }^{\#} p<0.05$ compared with corresponding wild-type mice.
A

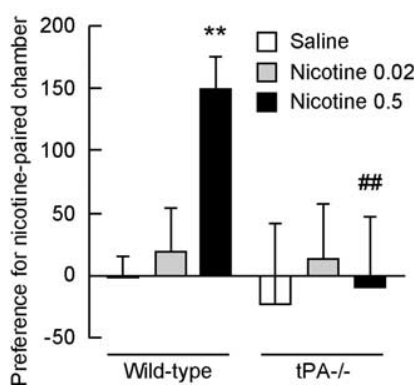

B

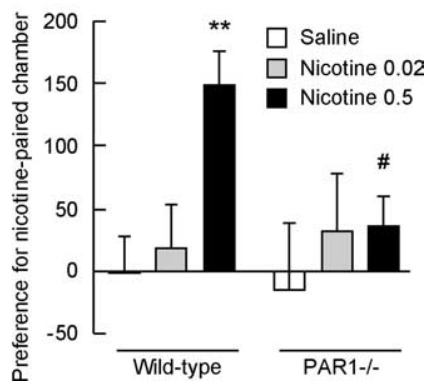

Figure 11. Nicotine-induced conditioned place preference in $P A^{-/-}$and $P A R 1^{-/-}$mice. Wild-type, $t P A^{-1-}(\boldsymbol{A})$, and $P A R 1^{-1-}(\boldsymbol{B})$ mice were trained for conditioned place preference with nicotine $(0.02$ or $0.5 \mathrm{mg} / \mathrm{kg}$, s.c.). Nicotine-induced conditioned place preference was diminished in $t P A^{-/-}\left(F_{(3,46)}=5.725 ; p<0.01\right)$ and $P A R 1^{-/-}\left(F_{(5,60)}=3.270 ; p<0.05\right)$ mice. Values represent the means \pm SEM $(n=8-17) .{ }^{* *} p<0.01$ compared with salinetreated wild-type mice. ${ }^{\#} p<0.05$ and ${ }^{\# \#} p<0.01$ compared with corresponding nicotinetreated wild-type mice.

VTA plays a crucial function in the release of dopamine (Mifsud et al., 1989). In the present study, in vivo microdialysis experiments showed that nicotine-induced dopamine release was potentiated by microinjections of either exogenous tPA or plasmin into the NAc, whereas local inhibition of tPA by PAI-1 in the NAc reduced the effect of nicotine on dopamine release. We also demonstrated that nicotine-induced dopamine release was attenuated in the NAc of $t P A^{-/-}$mice and that microinjections of either tPA or plasmin into the NAc restored the defect of nicotineevoked dopamine release in the mutant mice. Therefore, it is plausible that plasmin converted from plg by tPA may have a role in the regulation of nicotine-induced dopamine release in the NAc.

Nicotine stimulates the release of dopamine and other neurotransmitters, including ACh (Tran et al., 2001). A small but significant reduction of nicotine-induced $\mathrm{ACh}$ release was observed in the striatum and hippocampal CA1 subfield of $t P A^{-/-}$mice. Accordingly, it is likely that the release of ACh is also regulated, at least in part, by the tPA-plasmin system, although the contribution may be minimal.

Regarding the mechanism underlying the nicotine-induced tPA release in the NAc, we demonstrated that nicotine-induced tPA release was inhibited not only by the nAChR antagonist mecamylamine but also by the dopamine $D_{1}$ antagonist $\mathrm{SCH} 23390$ or the $\mathrm{D}_{2}$ receptor antagonist raclopride. Accordingly, we propose the following scenario for the nicotine-induced tPA release in the NAc: nicotine activates dopamine release through the activation of high-affinity nAChRs on presynaptic dopaminergic neurons, and the resultant activation of postsynaptic dopamine $\mathrm{D}_{1}$ and $\mathrm{D}_{2}$ receptors would cause tPA release from densecore granules in postsynaptic dendritic spines, as demonstrated recently with fluorescent tPA chimeras (Lochner et al., 2006).

The protein levels of tPA were increased in the neuronal cells of NAc after nicotine treatment. Although precisely how nicotine induces tPA expression is unclear, transcriptional and/or translational mechanisms have been proposed. There are cis-acting sites, in the proximal promoter region of the tPA gene, encoding a cAMP-responsive element (CRE)-like element (Costa et al., 1998). Nicotine increases phosphorylated CRE-binding protein levels in the NAc and VTA (Walters et al., 2005). Furthermore, a recent study has demonstrated that tPA expression in the hippocampal neuron is also under translational control and that glutamate elicits the immediate synthesis of tPA (within $20 \mathrm{~min}$ ) in the synaptic regions in which polyadenylation of tPA mRNA occurs (Shin et al., 2004). Therefore, we measured expression of tPA mRNA in the NAc after single administration of nicotine using a real-time reverse transcription-PCR method. Nicotine, however, had no effect on the levels of tPA mRNA in the NAc of mice at any doses $(0.02-1.0 \mathrm{mg} / \mathrm{kg})$ or time points $(0.5-24 \mathrm{~h})$ examined (data not shown). Therefore, the translational control system of tPA expression may be activated by nicotine.

In the present study, we obtained evidence that PAR1 is critically involved in the regulation by the tPA-plasmin system of nicotine-induced dopamine release and rewarding effect. PAR1 has been shown to respond to a highly selective group of serine proteases, including thrombin (Vu et al., 1991), plasmin ( $\mathrm{Ku}-$ liopulos et al., 1999; Loew et al., 2000), Xa (Riewald et al., 2001), and activated protein C (Riewald et al., 2002). Proteolytic cleavage exposes a new $\mathrm{N}$ terminus that binds to the body of the receptor to induce transmembrane signaling to internally located G-protein subunits, $\mathrm{G} \alpha_{\mathrm{q}}, \mathrm{G} \alpha_{\mathrm{i}}$, and $\mathrm{G} \alpha_{12 / 13}$ (Coughlin, 2000). We showed that plasmin activated PAR1 in the striatal membranes by using the $\left[{ }^{35} \mathrm{~S}\right] \mathrm{GTP} \gamma \mathrm{S}$ binding assay and that PAR1 immunoreactivity was localized to the nerve terminals positive for $\mathrm{TH}$ in the NAc and to the soma positive for TH in the VTA. Deletion of the PAR1 gene as well as microinjection of a PAR1 antagonist into the NAc reduced the nicotine-induced dopamine release. Moreover, 
the PAR1 antagonist diminished the effect of plasmin, which restored the nicotine-evoked dopamine release in $t P A^{-/-}$mice. These results suggest that nicotine-induced dopamine release in the NAc is positively regulated by the tPA-plasmin-PAR1 signaling.

Nicotine-induced place preference, which is associated with dopaminergic activation in the NAc, was significantly attenuated in $t P A^{-1-}$ and $P A R 1^{-/-}$mice compared with wild-type mice, suggesting that the tPA-plasmin-PAR1 signaling participates in the rewarding effects of nicotine. We demonstrated previously that there are no differences in dopamine-induced increases in $\left[{ }^{35} \mathrm{~S}\right] \mathrm{GTP} \gamma \mathrm{S}$ binding, apomorphine-induced hyperlocomotion, and TH protein levels between wild-type and $t P A^{-1-}$ mice (Nagai et al., 2004). Accordingly, it is likely that the changes to the rewarding effects of nicotine in $t P A^{-/-}$mice are mainly attributable to dopamine release and not to dysfunctional dopamine receptors.

The molecular mechanisms by which PAR1 regulates nicotine-induced dopamine release in the NAc remain to be determined. However, it is known that PAR1 couples to several different G-proteins. The principal signaling pathway is through $\mathrm{G} \alpha$-protein, resulting in activation of phospholipase $\mathrm{C} \beta$, hydrolysis of phosphoinositide, and the formation of inositol triphosphate and diacylglycerol, leading to the mobilization of $\mathrm{Ca}^{2+}$ (Hung et al., 1992). Our previous study has shown that a lack of tPA significantly attenuated the depolarization-evoked dopamine release in the NAc (Nagai et al., 2004). Recently, we also observed that PAR1 antagonists reduce depolarization-evoked dopamine release (our unpublished data). Therefore, it is possible that a defect in PAR1 signaling may result in a malfunction of $\mathrm{Ca}^{2+}$ mobilization activity, which leads to the reduction in dopamine release.

Pharmacotherapy most widely used for managing tobacco dependence and withdrawal is nicotine replacement therapy (NRT) (Henningfield et al., 2005). NRT make it easier to abstain from tobacco by replacing, at least partially, nicotine formerly obtained from tobacco and thereby proving some nicotine effects. Clinical studies suggested that NRT suppressed some withdrawal symptoms but left smokers vulnerable to craving and relapse when they confront smoking cues (Shiffman et al., 2006). In light of the present findings, we propose that targeting the tPA-plasmin-PAR1 system would provide new approaches to the treatment of nicotine dependence.

\section{References}

Baranes D, Lederfein D, Huang YY, Chen M, Bailey CH, Kandel ER (1998) Tissue plasminogen activator contributes to the late phase of LTP and to synaptic growth in the hippocampal mossy fiber pathway. Neuron 21:813-825.

Berrendero F, Kieffer BL, Maldonado R (2002) Attenuation of nicotineinduced antinociception, rewarding effects, and dependence in $\mu$-opioid receptor knock-out mice. J Neurosci 22:10935-10940.

Calabresi P, Napolitano M, Centonze D, Marfia GA, Gubellini P, Teule MA, Berretta N, Bernardi G, Frati L, Tolu M, Gulino A (2000) Tissue plasminogen activator controls multiple forms of synaptic plasticity and memory. Eur J Neurosci 12:1002-1012.

Carmeliet P, Schoonjans L, Kieckens L, Ream B, Degen J, Bronson R, De Vos R, van den Oord JJ, Collen D, Mulligan RC (1994) Physiological consequences of loss of plasminogen activator gene function in mice. Nature 368:419-424.

Center for Disease Control (2002) Cigarette smoking among adults in the United States, 2002. Morbid Mortal Weekely Rep 51:300-303.

Connolly AJ, Ishihara H, Kahn ML, Farese Jr RV, Coughlin SR (1996) Role of the thrombin receptor in development and evidence for a second receptor. Nature 381:516-519.
Corringer PJ, Le Novere N, Changeux JP (2000) Nicotinic receptors at the amino acid level. Annu Rev Pharmacol Toxicol 40:431-458.

Costa M, Shen Y, Maurer F, Medcalf RL (1998) Transcriptional regulation of the tissue-type plasminogen-activator gene in human endothelial cells: identification of nuclear factor that recognise functional elements in the tissue-type plasminogen-activator gene promoter. Eur J Biochem 258:123-131.

Coughlin SR (2000) Thrombin signalling and protease-activated receptors. Nature 407:258-264.

Dani JA, De Biasi M (2001) Cellular mechanisms of nicotine addiction. Pharmacol Biochem Behav 70:439-446.

Dery O, Corvera CU, Steinhoff M, Bunnett NW (1998) Proteinaseactivated receptors: novel mechanisms of signaling by serine proteases. Am J Physiol 274:C1429-C1452.

di Porzio U, Daguet MD, Glowinski J, Prochiantz A (1980) Effect of striatal cells on in vitro maturation of mesencephalic dopaminergic neurones grown in serum-free conditions. Nature 288:370-373.

Franklin JBJ, Paxinos GT (1997) The mouse brain in stereotaxic coordinates. New York: Academic.

Grand RJ, Turnell AS, Grabham PW (1996) Cellular consequences of thrombin-receptor activation. Biochem J 313:353-368.

Gualandris A, Jones TE, Strickland S, Tsirka SE (1996) Membrane depolarization induces calcium-dependent secretion of tissue plasminogen activator. J Neurosci 16:2220-2225.

Henningfield JE, Fant RV, Buchhalter AR, Stitzer ML (2005) Pharmacotherapy for nicotine dependence. CA Cancer J Clin 55:281-299.

Hung DT, Wong YH, Vu TK, Coughlin SR (1992) The cloned platelet thrombin receptor couples to at least two distinct effectors to stimulate phosphoinositide hydrolysis and inhibit adenylyl cyclase. J Biol Chem 267:20831-20834.

Jacovina AT, Zhong F, Khazanova E, Lev E, Deora AB, Hajjar KA (2001) Neuritogenesis and the nerve growth factor-induced differentiation of PC-12 cells requires annexin II-mediated plasmin generation. J Biol Chem 276:49350-49358.

Kuliopulos A, Covic L, Seeley SK, Sheridan PJ, Helin J, Costello CE (1999) Plasmin desensitization of the PAR1 thrombin receptor: kinetics, sites of truncation, and implications for thrombolytic therapy. Biochemistry 38:4572-4585.

Lee R, Kermani P, Teng KK, Hempstead BL (2001) Regulation of cell survival by secreted proneurotrophins. Science 294:1945-1948.

Lochner JE, Honigman LS, Grant WF, Gessford SK, Hansen AB, Silverman MA, Scalettar BA (2006) Activity-dependent release of tissue plasminogen activator from the dendritic spines of hippocampal neurons revealed by live-cell imaging. J Neurobiol 66:564-577.

Loew D, Perrault C, Morales M, Moog S, Ravanat C, Schuhler S, Arcone R, Pietropaolo C, Cazenave JP, van Dorsselaer A, Lanza F (2000) Proteolysis of the exodomain of recombinant protease-activated receptors: prediction of receptor activation or inactivation by MALDI mass spectrometry. Biochemistry 39:10812-10822.

Mataga N, Mizuguchi Y, Hensch TK (2004) Experience-dependent pruning of dendritic spines in visual cortex by tissue plasminogen activator. Neuron 44:1031-1041.

McGehee DS, Role LW (1995) Physiological diversity of nicotinic acetylcholine receptors expressed by vertebrate neurons. Annu Rev Physiol 57:521-546.

Mifsud JC, Hernandez L, Hoebel BG (1989) Nicotine infused into the nucleus accumbens increases synaptic dopamine as measured by in vivo microdialysis. Brain Res 478:365-367.

Nagai T, Yamada K, Yoshimura M, Ishikawa K, Miyamoto Y, Hashimoto K, Noda Y, Nitta A, Nabeshima T (2004) The tissue plasminogen activatorplasmin system participates in the rewarding effect of morphine by regulating dopamine release. Proc Natl Acad Sci USA 101:3650-3655.

Nagai T, Noda Y, Ishikawa K, Miyamoto Y, Yoshimura M, Ito M, Takayanagi M, Takuma K, Yamada K, Nabeshima T (2005a) The role of tissue plasminogen activator in methamphetamine-related reward and sensitization. J Neurochem 92:660-667.

Nagai T, Kamei H, Ito M, Hashimoto K, Takuma K, Nabeshima T, Yamada K (2005b) Modification by the tissue plasminogen activator-plasmin system of morphine-induced dopamine release and hyperlocomotion, but not anti-nociceptive effect in mice. J Neurochem 93:1272-1279.

Nakagami Y, Abe K, Nishiyama N, Matsuki N (2000) Laminin degradation by plasmin regulates long-term potentiation. J Neurosci 20:2003-2010. 
Narita M, Usui A, Narita M, Niikura K, Nozaki H, Khotib J, Nagumo Y, Yajima Y, Suzuki T (2005) Protease-activated receptor-1 and plateletderived growth factor in spinal cord neurons are implicated in neuropathic pain after nerve injury. J Neurosci 25:10000-10009.

Picciotto MR (2003) Nicotine as a modulator of behavior: beyond the inverted U. Trends Pharmacol Sci 24:493-499.

Pontieri FE, Tanda G, Orzi F, Di Chiara G (1996) Effects of nicotine on the nucleus accumbens and similarity to those of addictive drugs. Nature 382:255-257.

Riewald M, Kravchenko VV, Petrovan RJ, O’Brien PJ, Brass LF, Ulevitch RJ, Ruf W (2001) Gene induction by coagulation factor Xa is mediated by activation of protease-activated receptor 1. Blood 97:3109-3116.

Riewald M, Petrovan RJ, Donner A, Mueller BM, Ruf W (2002) Activation of endothelial cell protease activated receptor 1 by the protein $\mathrm{C}$ pathway. Science 296:1880-1882.

Sappino AP, Madani R, Huarte J, Belin D, Kiss JZ, Wohlwend A, Vassalli JD (1993) Extracellular proteolysis in the adult murine brain. J Clin Invest 92:679-685.

Scott ME, Dossani ZY, Sandkvist M (2001) Directed polar secretion of protease from single cells of Vibrio cholerae via the type II secretion pathway. Proc Natl Acad Sci USA 98:13978-13983.

Seeds NW, Basham ME, Haffke SP (1999) Neuronal migration is retarded in mice lacking the tissue plasminogen activator gene. Proc Natl Acad Sci USA 96:14118-14123.

Shiffman S, Ferguson SG, Gwaltney CJ, Balabanis MH, Shadel WG (2006) Reduction of abstinence-induced withdrawal and craving using highdose nicotine replacement therapy. Psychopharmacology 184:637-644.

Shin CY, Kundel M, Wells DG (2004) Rapid, activity-induced increase in tissue plasminogen activator is mediated by metabotropic glutamate receptor-dependent mRNA translation. J Neurosci 24:9425-9433.
Siao CJ, Fernandez SR, Tsirka SE (2003) Cell type-specific roles for tissue plasminogen activator released by neurons or microglia after excitotoxic injury. J Neurosci 23:3234-3242.

Striggow F, Riek-Burchardt M, Kiesel A, Schmidt W, Henrich-Noack P, Breder J, Krug M, Reymann KG, Reiser G (2001) Four different types of protease-activated receptors are widely expressed in the brain and are up-regulated in hippocampus by severe ischemia. Eur J Neurosci 14:595-608.

Tran MH, Yamada K, Olariu A, Mizuno M, Ren XH, Nabeshima T (2001) Amyloid $\beta$-peptide induces nitric oxide production in rat hippocampus: association with cholinergic dysfunction and amelioration by inducible nitric oxide synthase inhibitors. FASEB J 15:1407-1409.

Tsirka SE, Gualandris A, Amaral DG, Strickland S (1995) Excitotoxininduced neuronal degeneration and seizure are mediated by tissue plasminogen activator. Nature 377:340-344.

Vu TK, Hung DT, Wheaton VI, Coughlin SR (1991) Molecular cloning of a functional thrombin receptor reveals a novel proteolytic mechanism of receptor activation. Cell 64:1057-1068.

Walters CL, Cleck JN, Kuo YC, Blendy JA (2005) $\mu$-opioid receptor and CREB activation are required for nicotine reward. Neuron 46:933-943.

Weinstein JR, Gold SJ, Cunningham DD, Gall CM (1995) Cellular localization of thrombin receptor mRNA in rat brain: expression by mesencephalic dopaminergic neurons and codistribution with prothrombin mRNA. J Neurosci 15:2906-2919.

Yamada K, Nagai T, Nabeshima T (2005) Tissue plasminogen activator, synaptic plasticity and drug addiction. J Pharmacol Sci 97:157-161.

Zoli M, Moretti M, Zanardi A, McIntosh JM, Clementi F, Gotti C (2002) Identification of the nicotinic receptor subtypes expressed on dopaminergic terminals in the rat striatum. J Neurosci 22:8785-8789. 